\title{
Family Support And Lonely Elderly In Padang Bulan Kelurahan, Medan New District, Medan City
}

\section{Juni Magdalena}

Faculty Of Nursing, University Of North Sumatra, Jl. Dr. Mansur No. 9, Padan Bulan, Kec. Medan Baru, Kota Medan, 20222

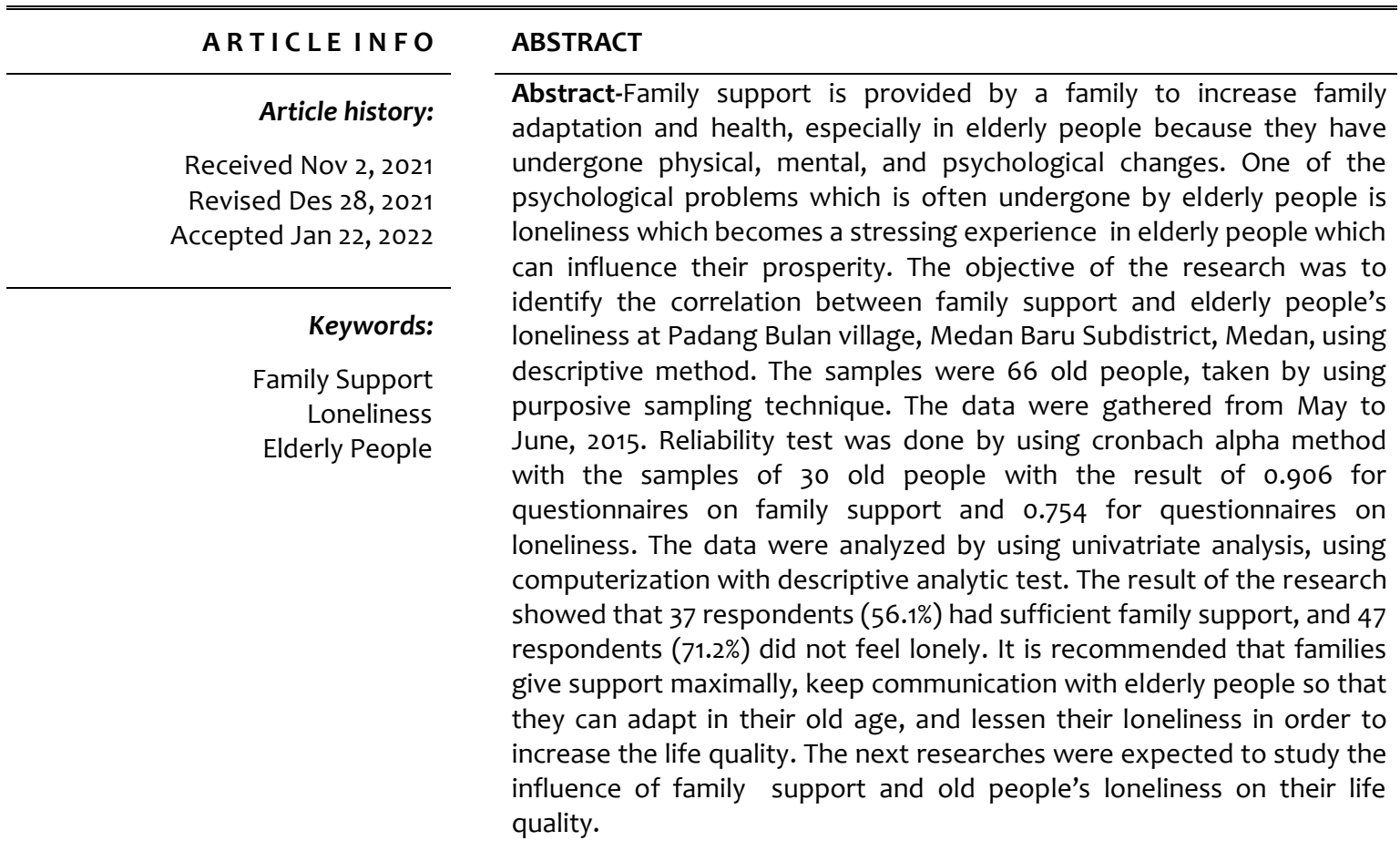

This is an open access article under the CC BY-NC license.

Corresponding Author:
Juni Magdalena,
Faculty Of Nursing,
University Of North Sumatra,
J. Dr. Mansur No.9, Padang Bulan, Kec. Medan Baru, Kota Medan, 20222.
Email: junimagdalena@gmail.com

\section{Introduction}

The Ministry of Health of the Republic of Indonesia (2013) explains that in Indonesia the number of elderly people 60 years is $18,861,820$ people, while the number of elderly people with high risk of 70 years is $7,621,845$ people. The population census conducted in Indonesia estimates that by 2020 the number of elderly people in Indonesia will increase to \pm 33 million people ( $12 \%$ of the total population) with a life expectancy of approximately 70 years (Nugroho, 2008). According to the 2010 population census (in BPS, 2013), North Sumatra has an elderly population of 767,700 out of a total population of 
$18,381,000$. The 2009 population census stated that the number of elderly people in Medan City was 134,896 people (BPS Kota Medan, 2009).

Elderly is not only determined by age, but is also characterized by a decrease in body functions and systems. Mubarak (2006) explains that entering old age means experiencing physical and psychological setbacks. Physical decline is characterized by loose skin, gray hair, decreased hearing, worsening vision, slow movement and abnormalities in various vital organ functions, accompanied by increased emotional sensitivity and lack of arousal. As a result of the changes that occur in the elderly, making the elderly need support from family members in meeting their needs, solving existing problems and dealing with old age (Ridlawati, 2012).

The family is the closest person and is a support system for the elderly in maintaining their health (Maryam et al., 2008). The family plays a very important role in providing support in the lives of the elderly, especially in the fulfillment of daily life because the elderly experience biological, physical, psychological and social changes, which have an influence on aspects of life, including their health. The health problems of the elderly need special attention by being maintained and improved so that they can live according to their abilities to the maximum extent possible (Mubarak, 2006).

Family support is a combination of attitude and acceptance that can help old people deal with problems (Estu, 2010 in Figa, Yaslinda \& Edison, 2012). The family support needed by the elderly includes informational support, emotional support, instrumental support and assessment support (House Smet, 1994 in Setiadi, 2008; Friedman, 2013).

Wahyu \& Vitria (2010) in their research explained that there was 5\% moderate family support and $56 \%$ good family support. Good family support makes the elderly feel safe, feel that someone is accompanying them and someone who cares about the existence of the elderly. Elderly who do not have good family support feel uneasy, have poor coping in solving problems, feel isolated and lonely.

Family support is also mentioned as an interpersonal relationship that can protect someone from bad effects, so that the elderly can enjoy life in old age, can be happy or feel happy to have support from people close to them. Lack of family support can increase mental and emotional problems experienced by the elderly, one of which is loneliness (Nusi, Rahayu, \& Eva 2010).

Cacioppo, Hawkley, \& Vanderweele (2012 in Jane Kimm Teh, Nai Peng, \& Sor Tho, 2014) explain that loneliness is a problem that is often experienced by the elderly. Weiss (1975 in Grif, 2009) states that loneliness is characterized as a lack of social intimacy or lack of social relationships.

Padang Bulan Village is one of the villages in Medan Baru District. The whole of Padang Bulan has elderly people who live with their family members. According to interviews conducted by researchers with 5 elderly people over 60 years old, the results showed that 4 elderly people had less family support because their family members were busy working and rarely communicated with their children and 3 elderly people felt lonely because there was rarely anyone to accompany them. The elderly choose to sit outside and interact with neighbors so that the elderly do not feel bored.

\section{Method}

The research design used in this study is a descriptive design, namely research conducted with the aim of explaining or describing the research problems that occur. This study describes family support and loneliness in the elderly.

The instrument used in this study was a questionnaire consisting of three parts, namely demographic data, family support questionnaire, and loneliness questionnaire in the elderly. Demographic data consists of gender, age, religion, marital status, ethnicity, latest education, occupation and living together.

The family support questionnaire aims to identify family support for the elderly. This questionnaire is in the form of a Likert scale consisting of 20 statements. Statements with the answer never will be given a score of 1, rarely will be given a score of 2, often given a score of 3, and always given a score of 4 . Family support in the form of informative support is represented by statements numbered 1-5. Emotional support is represented by statements number 6-10. Instrumental support is represented by 
statements number 11-15. Assessment support is represented by statements number 16-20. Data on family support are categorized into 3 ordinal classes. The lowest possible score is 20 and the highest score is 80 . The formula for determining class length: $P=$ range/many classes. Where $P$ is the length of the class with the highest value range minus the lowest value and divided by the number of classes. The highest score is 80 and the lowest score is 20 so that the class length $=(80-20) / 3=20$. So the results of the total score assessment are a score of 20-39 lacking family support, a score of 40-59 sufficient family support, a score of 60-80 good family support.

In conducting the analysis, the data is first processed with the aim of converting the data into information. Data processing is carried out through several stages consisting of editing to re-check the completeness of the respondent's data and ensure that all statements have been filled out. Furthermore, each questionnaire was coded (coding) to facilitate researchers in tabulating the data. After that, processing is carried out, namely entering data from the questionnaire that is entered into a computer program and processing the data using computerized techniques. Data analysis conducted in this research is univariate analysis which aims to describe the characteristics of research variables. The variables described are family support and loneliness in the elderly in the form of a frequency distribution table and its percentage.

\section{Analysis And Results}

\subsection{Family Support for the Elderly}

Research on family support for the elderly in Padang Bulan Village and Medan Baru District, Medan City, showed that the elderly who had good family support were 27 respondents (40.9\%) and those who received sufficient family support were 37 respondents (56.1\%) while who received less family support were 2 respondents (3.0\%). The results of research on family support can be seen in table 1 below:

Table 1

Distribution of Frequency and Percentage of Family Support to the Elderly in Padang Bulan Village, Medan Baru District, Medan

\begin{tabular}{lcc} 
& City $(\mathrm{n}=66)$ & \\
\hline Family support & Frequency $(\mathrm{n})$ & Percentage (\%) \\
\hline Well & 27 & 40.9 \\
Enough Less & 37 & 56.1 \\
& 2 & 3.0 \\
\hline Total & 66 & 100 \\
\hline
\end{tabular}

Based on table 1 above, it can be concluded that the largest family support for the elderly is in sufficient family support for 37 respondents (56.1\%).

\section{a. Loneliness in the Elderly}

Research on the loneliness of the elderly in Padang Bulan Village and Medan Baru District, Medan City, showed that the elderly who did not feel lonely were 47 respondents (71.2\%) and 18 respondents who experienced mild loneliness (27.3\%) were lonely. medium, namely 1 respondent (1.5\%). The results of research on loneliness can be seen in table 2 below:

Table 2

Distribution of Loneliness Frequency and Percentage in Elderly in Padang Bulan Village, Medan Baru Subdistrict, Medan City

\begin{tabular}{lcc}
\hline Lonely & $(\mathrm{n}=66)$ & Percentage (\%) \\
\hline Not Lonely & Frequency $(\mathrm{n})$ & 71.2 \\
Mild Loneliness & 47 & 27.3 \\
Moderate Loneliness & 18 & 1.5 \\
\hline Total & 1 & 100 \\
\hline
\end{tabular}


Based on table 2 above, it can be concluded that the majority of the elderly do not experience loneliness, namely 47 respondents (71.2\%).

The results showed that most of the respondents were elderly who were at the age of 60-74 years. At this age, family support is an important factor. The elderly experience many changes, both physiological and psychological. These changes cause the elderly to need assistance in meeting their daily needs. This is in accordance with Rahayu's research (2012 in Ikasi, 2014) explaining that the decline that occurs in someone who has entered old age will affect physical and psychological health, so that in this condition the family is expected to provide maximum support.

The results also showed that the elderly received an award from the family where the family tried to ask questions about the problems they felt, the solutions they got and involve the elderly in various family events. This research is in line with Nango's (2015) research which states that the presence and attention of the family is very important to give the elderly a great spirit of life and it is enough to make him feel relieved. The results of this study contradict the research of Figa, et al. (2012) which states that the lack of assessment support received by respondents is due to the lack of concern for other family members to what the respondent is doing, so that old age does not feel appreciated for their actions and old age will easily experience mental disorders.

Good family support is able to form a good self-concept in the elderly and increase enthusiasm in dealing with old age. In addition, a supportive family can fill the void felt by the elderly, so that the elderly do not feel lonely.

\section{Conclusion}

After conducting research on family support and loneliness in the elderly in Padang Bulan Village, Medan Baru District, Medan City, it can be concluded that the respondents who feel that family support is lacking are 2 respondents (3.0\%), 37 respondents (56.1\%) are sufficient and good as many as 27 respondents (40.9\%). The results also showed that 47 respondents (71.2\%), who did not feel lonely, experienced mild loneliness as many as 18 respondents (27.3\%) and 1 respondent (1.5\%). Family support has a great influence on the elderly in improving family health and adapting according to their developmental tasks and changes experienced by the elderly.

\section{References}

Afida. (2000). The Relationship Between Fulfillment of Affiliation Needs and Depression Levels in Elderly Women in Indonesian Nursing Homes. Taken on 15 August 2015 fromhttp://journal.lib.unair.ac.id

Arikunto. (2010). Research Procedure A Practical Approach (Revised Edition 2010). Jakarta: Rineka Cipta.

Baihaqi, MIF, et al. (2008). Psychiatry Basic Concepts \& Disorders.

Bandung: PT Refika Aditama

BPS. (2013). Indonesian Population Projection Indonesia Population Projection 2010-2035. Retrieved October 29, 2014 fromhttp://www.bps.go.id/

BPS Medan City. (2009). Retrieved October 29, 2014 fromhttp://www.pemkomedan.go.id/

Brehm \& Sharon. (2009). Intimate relationships. New York. Mc: Graw Hill Bruno, Frank J. (2000). Conquer Loneliness, Conquer Loneliness. Jakarta: PT Main Library Gramedia.

Darmojo. (2008). Textbook of Geriatrics (Elderly Health Sciences). Jakarta: FK UI Publishing Center.

Dyah. (2012). Loneliness in Old Age: A Study of Forms, Precipitating Factors and Coping Strategies. Journal of Nursing Universitas Muhammadiyah Purwokerto Accessed on 12 September 2014 fromhttp://digilib.ump.ac.id/ 
Dwi \& Fakhrurrozi. (2008). Elderly Lonely Men And Women Who Work And Not Work. Retrieved July 6, 2015 fromhttp://papers.gunadarma.ac.id.

Efendi, Ferry, Makhfudli. (2009). Community Health Nursing: Theory and Practice in Nursing. Jakarta: Salemba Medika.

Fatima. (2010). Caring for the Elderly A Gerontic Nursing Process Approach. Jakarta: TEAM.

Figa, Yaslinda, \& Edison. (2012). Relationship between Family Support and Depression in Old Age in Nagari Tanjung Banai Aur, Sumpur Kudus District, Sijunjung Regency in 2012. Taken on October 27, 2014 fromhttp://jurnal.fk.unand.ac.id.

Friedman. (2013). Textbook of Family Nursing Research, Theory, \& Practice. Jakarta: EGC.

Griff, JoAnn Alspach. (2013). Loneliness and Social Isolation Risk Factors Long Overdue for Surveillance. Critical Care Nurse Vol 33, No. 6 page 8-12, December 2013. Retrieved October 13, 2014 fromhttp://dx.doi.org/

Juniarti, Septi Eka, \& Asma Damayanti. (2008). Description of the Types and Levels of Loneliness in the Elderly at the Tresna Werdha Pakutandang Orphanage in Ciparay Bandung in 2008. Taken fromri http://library.unpad.ac.id/ on October 13, 2014.

Hidayat. (2009). Nursing Research Methods and Data Analysis Techniques. Jakarta: Salemba Medika.

Ikasi. (2014). Relationship of Family Support Against Loneliness in the Elderly. Taken on July 6, 2015 fromhttp://download.portalgaruda.org/

Indonesian Ministry of Health. (2013). Indonesia Health Profile 2014. Accessed on October 29, 2014 andri http://www.depkes.go.id/

Kimm, Jane Teh, Nai Peng, \& Sor Tho. (2014). Family Support and Loneliness among Older Perseons in Multiethnic Malaysia. The Scientific World Journal Volume 2014, Article ID 654382, 11 pages. Taken on December 13, 2014 dari http://dx.doi.org/

Kristyaningsih. (2011). The Relationship between Family Support and Depression Levels in the Elderly. Taken on 6 July 015 fromhttp://www.dianhusada.ac.id.

Maryam, Siti, Mia, Rosidawati, Ahmad, \& Irwan. (2008). Knowing the Elderly and Its Treatment. Jakarta: Salemba Medika.

meyji. (2012). Family Social Support for Elderly Living Alone. Taken on July 6, 2015 fromhttp://eprints.uny.ac.id

Mubarak. (2006). Textbook of Community Nursing 2: Theory \& Application in Practice with Community Nursing, Gerontics and Family Approaches and Care. Jakarta: Sagung Seto.

Nango. (2015). Relationship between Family Support and Depression in the Elderly at UPT Pasuruan Social Services for the Elderly in Lamongan. Gresik University Scientific Journal

Narang. (2013). INTERPERSONAL RELATIONSHIPS OF ELDERLY WITHIN.

THE FAMILY International Journal of Social Science \& Interdisciplinary Research IJSSIR. Taken on 6 July 2015 from http://indianresearchjournals.com.

net. (2012). Socio-Demographic Predictors of Loneliness Across the Adult Life Span in Portugal. Taken on July 6, 2015 fromhttp://interpesona.psychopen.eu.

Nugroho. (2008). Gerontology \& Geriatric Nursing. Jakarta: EGC 
Nursalam. (2007). Nursing care for HIV/AIDS-infected patients. Jakarta: Salemba Medika.

Nursalam. (2011). Concept and Application of Nursing Research Methodology Guidelines for Thesis, Thesis, and Nursing Research Instruments. Jakarta: Salemba Medika.

Notoadmojo. (2010). Health Research Methodology. Jakarta: Rineka Cipta Nusi, Rahayu, \& Eva. (2009). Relationship between Family Support and Social Response to the Elderly in Sokaraja Lor Village, Sukoraja District. Sudirman Journal of Nursing Volume 5 No. 1 March 2010 Retrieved 23 October 2014 dari http://jos.unsoed.ac.id/

Potter \& Perry. (2005). Teaching Fundamental Nursing Concepts, Processes, and Practices 4th Edition Jakarta: EGC.

Ridlawati. (2012). Relationship between Family Support and Elderly Independence with Elderly Self-Concept in Bamnamkerep Village, Ngaliyan District, Semarang City. Journal of Community Nursing Volume 1 No. May 1, 2013 pp. 18-23. Taken October 23, 2014 fromhttp://jos.unsoed.ac.id/

Sanjaya. (2012). Relationship between Social Interaction and Loneliness in the Elderly at UPT Social Services for Elderly and Toddlers in Binjai and Medan Regions.USU Thesis.

Septiningsih \& Na'imah. (2012). Loneliness in the Elderly: A Study of Forms, Precipitating Factors and Coping Strategies. Taken on 6 July 2015 dari http://ejournal.undip.ac.id.

Setiadi. (2008). Family Nursing Concepts and Processes. Yogyakarta: Graha Ilmu.

Smeltzer \& Bare. (2002). Textbook of Medical-Surgery Nursing Brunner \& Suddarth. Jakarta: EGC.

Tamher, S \& Noorkasiani. (2009). Elderly Health with Nursing Care Approach. Jakarta: Salemba Medika.

Taylor, Peplau, \& Sears. (2009). Social Psychology, Twelfth Edition. Jakarta: Kencana.

Taylor, Shelley E. (2009). Health Psychology 7th Edition. New York: McGraw- Hill Companies.

Thomopoulo \& Koutsouki. (2010). The Differences Quality of Life and Loneliness Between Elderly People. Taken on July 6, 2015 fromhttp://biologyofexercise.com.

Wahyu, Vitria Astuti. (2008). The Relationship between Family Support and Depression Levels in the Elderly at the Sejahtera Posyandu GBI Setia Bakti Kediri. Retrieved 29 October 2014 dari http://journal.unair.ac.id/

WHO. (2014). World Health Statistics 2014. Retrieved October 29, 2014 dari http://www.who.int/ 